\title{
Impact of whole dairy matrix on musculoskeletal health and aging-current knowledge and research gaps
}

\author{
N.R.W. Geiker ${ }^{1}$ (D) - C. Mølgaard ${ }^{1}$ (D) - S. Iuliano ${ }^{2} \cdot$ R. Rizzoli ${ }^{3} \cdot$ Y. Manios ${ }^{4} \cdot$ L.J.C. van Loon $^{5}$ (D) \\ J.-M. Lecerf ${ }^{6} \cdot$ G. Moschonis ${ }^{7}$ (D) - J.-Y. Reginster ${ }^{8} \cdot$ I. Givens $^{9} \cdot$ A. Astrup ${ }^{1}$ (I)
}

Received: 20 September 2019 / Accepted: 6 November 2019 /Published online: 14 November 2019

(C) The Author(s) 2019, corrected publication January 2020

\begin{abstract}
Dairy products are included in dietary guidelines worldwide, as milk, yoghurt, and cheese are good sources of calcium and protein, vital nutrients for bones and muscle mass maintenance. Bone growth and mineralization occur during infancy and childhood, peak bone mass being attained after early adulthood. A low peak bone mass has consequences later in life, including increased risk of osteoporosis and fractures. Currently, more than 200 million people worldwide suffer from osteoporosis, with approximately 9 million fractures yearly. This poses a tremendous economic burden on health care. Between 5\% and 10\% of the elderly suffer from sarcopenia, the loss of muscle mass and strength, further increasing the risk of fractures due to falls. Evidence from interventional and observational studies support that fermented dairy products in particular exert beneficial effects on bone growth and mineralization, attenuation of bone loss, and reduce fracture risk. The effect cannot be explained by single nutrients in dairy, which suggests that a combined or matrix effect may be responsible similar to the matrix effects of foods on cardiometabolic health. Recently, several plant-based beverages and products have become available and marketed as substitutes for dairy products, even though their nutrient content differs substantially from dairy. Some of these products have been fortified, in efforts to mimic the nutritional profile of milk, but it is unknown whether the additives have the same bioavailability and beneficial effect as dairy. We conclude that the dairy matrix exerts an effect on bone and muscle health that is more than the sum of its nutrients, and we suggest that whole foods, not only single nutrients, need to be assessed in future observational and intervention studies of health outcomes. Furthermore, the importance of the matrix effect on health outcomes argues in favor of making future dietary guidelines food based.
\end{abstract}

Keywords Bone $\cdot$ Cheese $\cdot$ Fermented dairy products $\cdot$ Milk $\cdot$ Muscle

\section{Abbreviations}

BMD Bone mineral density

BMC Bone mineral content
$\mathrm{Ca}$
Calcium
$\mathrm{Ca}: \mathrm{P} \quad$ Calcium-to-phosphorus ratio
CHD Coronary heart disease

The original version of this article was revised due to a retrospective Open Access order.

N.R.W. Geiker

geiker@nexs.ku.dk

1 Department of Nutrition, Exercise and Sports, Faculty of Science, University of Copenhagen, Rolighedsvej 26, DK-1958, Frederiksberg C, Denmark

2 Department of Endocrinology, University of Melbourne, Austin Health, Melbourne, Australia

3 Division of Bone Diseases, Geneva University Hospitals and Faculty of Medicine, Geneva, Switzerland

4 Department of Nutrition \& Dietetics, Harokopio University, Athens, Greece
5 NUTRIM School of Nutrition and Translational Research in Metabolism, Department of Human Biology, Maastricht University Medical Centre+, Maastricht, the Netherlands

6 Department of Nutrition and Physical Activity, Institut Pasteur de Lille, Lille, France

7 Department of Dietetics, Nutrition and Sport, La Trobe University, Melbourne, Australia

8 World Health Organization Collaborating Center for Public Health Aspects of Musculoskeletal Health and Aging, University of Liège, Liège, Belgium

9 Institute for Food, Nutrition and Health, University of Reading, Reading, United Kingdom 


$\begin{array}{ll}\text { CI } & \text { Confidence interval } \\ \text { CVD } & \text { Cardiovascular disease } \\ \text { FGF } & \text { Fibroblast growth factor } \\ \text { HDL } & \text { High-density lipoprotein } \\ \text { IGF-1 } & \text { Insulin-like growth factor-1 } \\ \text { IL } & \text { Interleukin } \\ \text { LDL } & \text { Low-density lipoprotein } \\ \text { MFG } & \text { Milk fat globule } \\ \text { MFGM } & \text { Milk fat globule membrane } \\ \text { MUFA } & \text { Monounsaturated fatty acids } \\ \text { NA } & \text { Not assessed } \\ \text { PBM } & \text { Peak bone mass } \\ \text { P } & \text { Phosphate } \\ \text { RCT } & \text { Randomized controlled trials } \\ \text { RE } & \text { Retinol equivalent } \\ \text { RR } & \text { Relative risk } \\ \text { SCFA } & \text { Short-chain fatty acids } \\ \text { SF } & \text { Saturated fat } \\ \text { SFA } & \text { Saturated fatty acids } \\ \text { TFA } & \text { Trans fatty acids } \\ \text { TG } & \text { Triglyceride } \\ \text { TNF- } \alpha & \text { Tumor necrosis factor-alpha } \\ \text { UHT } & \text { Ultra-high temperature processing }\end{array}$

\section{Introduction}

Dietary recommendations have historically focused on single nutrients, with levels aimed at ensuring intakes sufficient to meet bodily requirements in the different phases of life: infancy, childhood, adolescence, adulthood, and old age. Additionally, specific recommendations have been made for pregnant and lactating women, and for ill individuals, circumstances where requirements may be increased. In most cases, recommendations describe age- and gender-specific intakes sufficient to meet requirements in $97-98 \%$ of the given population, and an upper level, of which the intake should remain below. Often, determination of a recommended level is based on a combination of evidence from randomized controlled trials (RCTs), observational and mechanistic studies, and on meta-analyses.

The recommended intakes of nutrients are given in measures not easily understood by the public, e.g., protein is given in grams per kilogram of body weight and sometimes also as grams per day, percentage of total energy intake, or even as percentage of food energy intake and calcium in milligrams per day $[1,2]$. Furthermore, people consume foods not nutrients, and translation from individual nutrients to foods has proven problematic for both health professionals as well as the general public [3].

In observational studies, dietary intakes are often assessed by questionnaires with predefined categories, and different foods are generally grouped to match the focus of the given investigation. Studies assessing the association between saturated fatty acid (SFA) intake and risk or incidence of mortality from coronary heart disease (CHD) are inconsistent, yet the WHO draft guidelines recommend limiting intake of saturated fat to $10 \%$ or less of total energy intake [4]. A recent review of the evidence from both interventional and observational studies concluded that the health effects of SFA vary greatly depending on the specific fatty acid, that some foods containing SFA are often sources of essential nutrients, and that RCTs have found foods such as cheese and dark chocolate to have beneficial effects on cardiovascular biomarkers [5].

The importance of sufficient dietary intake and absorption of protein and vitamin $\mathrm{D}$ for optimal muscle strength is well proven, and recently a gut-muscle axis, a cross-talk between the gut microbiota and muscle, has been found to be important for muscular size, strength, and function [6]. Similarly, a link between gut microbiota and bone exists, influencing bone strength and mineral density beyond the effect of calcium, phosphorus, and protein intake (see Rizzoli et al. 2019 for review [7]). The consumption of fermented dairy products containing pre- and probiotics may possibly induce changes in hormones and cytokines, e.g., reduce parathyroid hormones and tumor necrosis factor-alpha (TNF- $\alpha$ ), causing a reduction in bone resorption and an increase in insulin-like growth factor-I (IGF-I), thus leading to increased bone formation and affecting the absorption of calcium [8].

The above highlights the necessity of viewing and investigating dairy as a whole food exerting matrix effects than focusing on single nutrients or the sum of single nutrients. This will allow for more practical and food-based nutritional recommendations.

\section{Aim and methods}

The present paper is based on the presentations, discussions, and conclusions of an expert workshop on the dairy matrix and musculoskeletal health held in June 2019, completing and extending a previously published expert workshop report on dairy matrix and cardiovascular disease (CVD) held in September 2016. The conclusion of the latter was that dairy foods can have different and more beneficial effects on bone health than would be expected solely on the basis of the sum of the effects of the individual nutrients, and that overall composition and structure of foods needs to be considered, i.e., the food matrix effects. Gaps in current knowledge that warrant further exploration were identified. Aspects of protein and muscle metabolism were also considered, but there is a need for a more in-depth appraisal. As bone and muscle health (and the related disease states of osteoporosis and sarcopenia) are intrinsically linked, it was proposed that a subsequent workshop should address the wider aspects of musculoskeletal health for a more comprehensive outcome.

Therefore, the aims of this 2019 workshop were to explore current knowledge on the impact of whole dairy matrix on muscle and bone, specifically focusing on fermented dairy 
products and musculoskeletal health and aging, and to identify research gaps.

\section{Musculoskeletal health and the aging population}

Currently, more than 200 million people worldwide suffer from osteoporosis, and with an increasingly aging population, this number is expected to increase by approximately $30 \%$ in the nearer future. According to the International Osteoporosis Foundation, in the year 2000, osteoporosis was estimated to cause more than 8.9 million new fractures globally, with 1.6 and 1.7 million being hip and forearm fractures, respectively, and 1.4 million being clinical vertebra fractures, making osteoporosis considered a serious health problem. Nearly one in two women and one in five men older than 50 years will experience at least one osteoporotic fracture during the latter half of their life. Including the secular trends of the global population, the risk of hip fractures are projected to increase dramatically by the year $2050[9,10]$.

The incidence of hip fractures is associated with increased mortality and represents a tremendous burden on healthcare finances. With sound justification, the US National Osteoporosis Foundation has rated calcium and dairy with the highest evidence grade in their class as important modifiable lifestyle factors influencing the development of peak bone mass (PBM) [11].

Sarcopenia, an age-related progressive loss of muscle mass and function, is, like osteoporosis, a major clinical problem among the elderly population. In Europe, low muscle strength is the primary indicator [12]. Among Western populations, approximately $19 \%$ to $20 \%$ of otherwise healthy men and women above the age of 60 years suffer from sarcopenia [13]. The consequences of sarcopenia are many and severe, e.g., reduced muscle strength increases the risk of falls causing bone fractures leading to decreased mobility, disability, and a reduced quality of life. A more recently acknowledged consequence is the increased risk of metabolic disorders, as type 2 diabetes is caused both due to low physical activity levels and reduced muscle mass in the elderly [14]. Increased dietary intake of protein, preferably in combination with physical activity or exercise, has been proven effective to augment the gains in muscle mass and strength [15]. Furthermore, studies have shown a higher anabolic stimuli of muscle protein synthesis, following ingestion of dairy over plant-based proteins [16-18].

The following sections in the present paper will describe the scientific evidence on the effect of dairy products and its matrix in relation to musculoskeletal health.

\section{The concept of food matrix compared to single nutrients-the case for cardiovascular disease}

Dairy is a major source of saturated fat. Previous meta-analyses, on which several dietary guidelines are based, have identified SFA to be associated with increased risk of cardiovascular disease [19]. Arguing that high plasma low density lipoprotein (LDL) cholesterol is a key risk factor for coronary artery disease $[19,20]$, the European Food Safety Authority advocates not only keeping dietary intake of saturated fatty acids below $10 \%$ of energy intake but to keep it as low as possible [21]. In the current US dietary guidelines, the advice is to consume "Fat-free or low-fat dairy, including milk, yoghurt, cheese," i.e., to avoid or at least reduce SFA intake. Current Nordic Nutrition Recommendations and American Heart Association guidelines advise a shift from whole fat to low fat dairy products $[1,2,22]$.

Recent research has shown that SFAs, as a group, do not exert the adverse effect on CVD as previously believed, and that the various SFA exert very different biological effects, and that health effects are substantially modified by the food matrix [23-25]. One example is cheese, which might be expected to increase CVD risk due to its high content of SFA and sodium, but studies indicate the opposite, with a reduction in blood pressure, and reduced risk of CVD and particularly of stroke with increased cheese consumption [26-28]. Similarly, an updated meta-analysis including 29 cohort studies found inverse associations between total intake of fermented milk products, including soured products, yoghurt, and cheese [29].

Moreover, dairy consumption during energy intake restriction is among 12 RCTs associated with a reduction in fat mass by $1.11 \mathrm{~kg}(95 \% \mathrm{CI}-1.75$ to $-0.47, P=0.001)$ and increased body lean mass by $0.72 \mathrm{~kg}(95 \% \mathrm{CI} 0.12$ to $1.32, P=0.02)$ [30].

The effect of a given nutrient may vary dramatically depending on the composition, which may account for the observed different effects of dairy products, whether fermented or not. Some of these differences may have consequences for dietary guidelines for local populations, for harmonizing guidelines across countries, and for the health maintenance/ disease prevention outcomes of the guidelines.

Maintaining the general advice to reduce total SFA will work against the intentions of dietary advice, and weaken the impact of dietary guidelines on chronic disease incidence and mortality. A food-based translation of the recommendations for SFA intake would avoid unnecessary reduction or exclusion of foods that may have important health benefits [5]. Provided the current scientific knowledge, there are no unfortunate consequences for consuming dairy, especially fermented, as part of a healthy and varied diet.

\section{The dairy food matrix and plant-based alternatives in relation to bone and skeletal muscle health}

Dairy products represent one of the five core food groups embedded in most dietary guidelines worldwide. Recent updates of dietary guidelines in the USA and Australia [2] have included plant-based alternatives, especially soy-based 
products, to the dairy food group, to accommodate those who may do not consume dairy foods such as vegans or those with lactose intolerance. These are often presented as suitable alternatives to milk, though nutritionally their content may not compare at all, especially for products essentially devoid of protein (Table 1). The small number of prospective studies and RCTs comparing dairy products with plant-based alternatives indicate that dairy appears more beneficial for bone health $[31,32]$.

\section{Milk drink or plant-based beverage?}

In the EU, with the exception of coconut, only beverages produced by the mammary glands are permitted to use the term "milk" in their description when marketed in the EU, and only when obtained from one or more milkings without either addition thereto or extraction therefrom [33]. "Dairy products" refers to products derived exclusively from milk, e.g., whey, cream, butter, buttermilk, cheese, and yoghurt. The names or descriptions of products of plant origin are, by legislation, not allowed to contain the words milk, cheese, or yoghurt. Nonetheless, several manufacturers of plant-based alternatives use "milk" when describing their product.

Dairy milk has a higher protein content than the majority of its plant-based alternatives, which stimulates the synthesis of growth factors like IGF-I and promotes bone formation (Table 1) [35, 36]. Soy-based drinks have similar levels of protein as milk, but animal sources of protein tend to be more easily digested, and the distribution of the nine essential amino acids is considered to be better aligned with human requirements, particularly for muscle and bone formation [37].

Bone is a dynamically changing structure, with mineral deposition beginning in utero, and with bone mineral content (BMC) increasing 40-fold from birth until the end of the second decade of adult life, when PBM is achieved. Factors within the dairy matrix other than protein and calcium content may play an important role in the effect of dairy on growth. At 12 weeks postnatal, infants receiving a high sn- 2 palmitate formula (i.e., mimicking the sn-2 palmitate content of human milk) since birth had significantly greater absorption of fat and calcium, and higher bone strength compared to infants receiving a regular formula with low sn-2 palmitate [38]. Approximately $40 \%$ to $60 \%$ of adult bone mass accrues during adolescence and milk intake during childhood and adolescence has been associated with higher BMC, with consumption of more than three servings of milk per day associated with a greater adult height in girls compared to those drinking less than one serving per day [31]. For each cup of plant-based drink relative to milk, children were $0.4 \mathrm{~cm}(95 \%$ CI $0.2-0.8$ $\mathrm{cm})$ shorter. Though not fully understood, the increasing effect of dairy on height growth among children and adolescents may be due to a combining effect of IGF-I, growth hormone, and the milk proteins whey and casein [39].

An RCT in 141 postmenopausal women found consumption of milk superior in preventing BMD loss at the hip and femoral neck over an 18-month period compared to soy drink [32]. Although the calcium intake was similar in both groups, the observed skeletal differences were attributed to a potentially higher bioavailability of calcium from milk.

\section{Bioavailability}

Calcium bioavailability in plant sources varies considerably, partially due to the presence of absorption inhibitors such as oxalates and phytates. In addition to calcium, milk also has a high concentration of other micronutrients, such as phosphorus, magnesium, potassium, and vitamin $\mathrm{A}$, which are important for bone health. It also serves as a good substrate for fortification with vitamin D (i.e., fat-soluble vitamin) due to milk's fat content.

Table 1 The nutritional profile of cow's milk and plant-based alternatives, with and without fortification (nutritional content per $100 \mathrm{~mL}$ of beverage)

\begin{tabular}{|c|c|c|c|c|c|c|c|c|}
\hline & Milk & Soy drink & Soy drink, fortified & Almond drink & Rice drink & Rice drink, fortified & Oat drink & Oat drink, fortified \\
\hline Energy, kcal & 64 & 55 & 45 & 47 & 50 & 54 & 50 & 45 \\
\hline Energy, kJ & 268 & 230 & 188 & 197 & 209 & 226 & 209 & 188 \\
\hline Protein, $g$ & 3.4 & 3.1 & 3.3 & 0.7 & 0.1 & 0.1 & 0.6 & 0.5 \\
\hline Total lipid, $\mathrm{g}$ & 3.5 & 2.3 & 1.9 & 2.2 & 0.9 & 0.9 & 1 & 1.6 \\
\hline Carbohydrate, $\mathrm{g}$ & 4.9 & 5.3 & 3.6 & 5.9 & 10.3 & 11.4 & 9.7 & 7.2 \\
\hline Vitamin A, RE & 35.3 & 0 & 0 & 0 & 0 & 0 & 0.34 & 0 \\
\hline Vitamin $\mathrm{B}_{2}, \mathrm{mg}$ & 0.18 & 0.01 & 0.02 & 0.02 & 0 & 0 & 0.01 & 0.01 \\
\hline Vitamin $B_{12}, \mu g$ & 0.39 & 0 & NA & NA & NA & NA & NA & NA \\
\hline Calcium, mg & 119.0 & 9.86 & 74.5 & 8.8 & 1.85 & 84.3 & 6.56 & 126.0 \\
\hline Zinc, mg & 0.36 & 0.25 & 0.28 & 0.11 & 0.03 & 0.05 & 0.41 & 0.08 \\
\hline Iron, mg & 0.02 & 0.45 & 0.50 & 0.12 & 0.01 & 0.23 & 0.03 & 0.44 \\
\hline Iodine, $\mu \mathrm{g}$ & 16.5 & 1.3 & 9.35 & 0.89 & 1.04 & 2.5 & 0.418 & 5.9 \\
\hline Phosphorus, mg & 91.0 & 44.1 & 41.5 & 14.3 & 7.39 & 28.0 & 13.2 & 16.9 \\
\hline
\end{tabular}

Data from the Danish National Food Institute [34]

RE retinol equivalents, NA not assessed 
Calcium bioavailability is determined by both its chemical structure and by interrelation with other nutrients in the diet, e.g., phosphorus. A limited number of papers have assessed the bioavailability of calcium in milk versus soy beverage. Available data indicate that bioavailability in soy drink is dependent on the chemical structure of the added calcium. Tricalcium phosphate is not as bioavailable as the calcium in cow's milk [40], while the bioavailability of calcium carbonate is in some studies found similar to that of calcium in cow's milk while in others found to have a less positive effect on bone formation [41-43]. However, the specific type of calcium is most often not specified in the list of ingredients on fortified plant-based beverages, making it difficult for the consumer to make an informed choice. Given the potentially large impact of dairy calcium, we call for high-quality studies investigating the effect of different dairy matrices on musculoskeletal health.

The calcium-to-phosphorus ratio (Ca:P) in foods is a determining factor for mineral absorption and for the formation of structural bone matrix [42]. To meet the requirements at the different stages of growth, the recommended range of Ca:P intake ratio is $1: 1$ and 2:1 in adults and children, respectively [44]. The ratio ( $w / w)$ of Ca:P in cow's milk is $1.3: 1$, whereas it is $0.2: 1$ in unfortified and 1.8:1 in fortified soy drink. However, the bioavailability of the type of calcium used for fortification of plant-based alternatives may result in a much lower absorption ratio. Both phytate and oxalic acid, present in cereals, bran, soybean, and nuts, bind with calcium and reduce calcium absorption dose dependently [45]. Moreover, the high content of oxalate in the plant-based beverages, in particular almond drink, has led to concern of risk of hyperoxaluria and genitourinary disorders in children ingesting these drinks on a daily basis [46].

Little is known about the bioavailability of other minerals, vitamins, and trace elements in plant-based alternatives to milk. More research is needed to fully understand the bioavailability of nutrients in different foods, the possible effects of one food on the bioavailability of nutrients from other foods ingested at the same time, and the potential interaction of nutrients used for the fortification of plant-based alternatives that might affect nutrient bioavailability.

Fermented dairy products are reported to be more potent than other milk products in increasing absorption of nutrients [47]. This is likely due to their pre- and pro-biotic content and their beneficial effect of gut microflora, calciotrophic and growth hormones, and intestinal inflammation, which consequently lead to inhibition of bone resorption and stimulation of bone formation. Fermentation of calcium-fortified soy drink, on the other hand, does not improve acute calcium absorption in women with subnormal or normal vitamin D status [8, 47-49].

However, bioavailability is irrelevant if the nutrient stated to be present in the drink does not actually reach the consumer. A simple assessment of how much calcium is present in a glass of fortified soy drink showed that the calcium content was just $31 \%$ of the declared content when poured unshaken, and shaking only resulted in an improvement to $59 \%$ of the declared content. Indeed, one sample failed to reach $20 \%$ of declared calcium content when shaken [50].

Dairy is also a major source of vitamin $\mathrm{B}_{12}$, important for the nervous system, cognitive function, and blood cell health, while plant-based alternatives do not contain vitamin $B_{12}$ and are not fortified with it (Table 1). Deficiency of vitamin $B_{12}$ can take several years to develop and is difficult to measure, as both serum and plasma stores are maintained for some time by compensatory release of vitamin $\mathrm{B}_{12}$ from tissue. Low levels would represent long-term deficiency. Substitution of plantbased drinks for milk without alternative sources of vitamin $\mathrm{B}_{12}$ in the diet may not only compromise skeletal and muscle growth but may also have detrimental effects on the nervous system and blood cells.

Based on the content of nutrients, there is little evidence to indicate that plant-based alternatives would exert the same beneficial effects as dairy products on bone, but to our knowledge, there are no intervention studies assessing the effect of plant-based alternatives on bone. Therefore, to evaluate the effect of exchanging plant-based alternatives for milk, highquality RCTs and/or prospective studies are needed.

\section{The role of nutrients and the food matrix on growth and bone health in children and adolescence: consequences for later life}

During development from infancy to adulthood, bones grow in length, width, and density at varying rates, until reaching PBM in early adulthood. Bone mass declines gradually thereafter, the rate of decline increasing significantly in women at menopause before achieving a new level, after which it declines gradually. It is generally accepted that PBM is one of the main predictors of later fracture risk in adulthood and old age [51]. Depending on the skeletal site, PBM is typically reached at age 20 to 30 years. Bone growth and mineralization during infancy, childhood, and adolescence are important for optimizing PBM and may influence the risk of osteoporosis in later life. A 10\% increase in PBM in females could theoretically be estimated to delay the onset of postmenopausal osteoporosis by up to 13 years [52]. Total bone mass is influenced by bone size, length, width, and density, i.e., the accrual of minerals within the bone.

In mammals, including humans, intake of milk occurs during periods of high growth rates, especially early in life. All mammals feed on milk from birth through early infancy, and in some species, this continues for several years when growth rate is high. In humans, after weaning, many children continue to consume milk and other dairy products (mainly bovine), and in populations that are lactose tolerant, it is common to continue consumption throughout life. 
Several nutrients play a role in bone health during growth; those with an expected positive influence include calcium, vitamin $\mathrm{D}$, vitamin $\mathrm{K}$, and high-quality protein. Milk and dairy products are rich in calcium and high-quality protein, and also contain many other minerals, and almost all vitamins and factors stimulating growth [53]. In 1998, Bogin presented the "milk hypothesis": a prediction that a greater consumption of milk during infancy and childhood would result in taller stature later in life $[54,55]$. Bogin implies that there is a "height factor" in dairy, which is likely to be a nutrient, or a combination of nutrients. This is supported by observational studies reporting associations between milk intake and linear growth among well-nourished populations [56], suggesting that milk has a growth-stimulating effect even when nutrient intake is adequate. The strongest evidence that cow's milk stimulates linear growth comes from observational and intervention studies in low-income countries. A meta-analysis of intervention studies found that $245 \mathrm{~mL}$ milk supplementation daily resulted in $0.4 \mathrm{~cm}$ extra growth per year in children in both developed and developing countries. The effect of milk consumption on linear growth was higher in children with lower height-for-age and who were peripubertal [57]. However, an effect of milk and milk-product consumption on linear growth was not replicated in a more recent metaanalysis including RCTs. This meta-analysis indicated that children and adolescents consuming dairy products were more likely to achieve a lean body phenotype due to greater increase in lean body mass $(0.21 \mathrm{~kg} ; 95 \%$ CI $0.01,0.41 \mathrm{~kg} ; P<0.05)$ and simultaneously reduction in percentage fat mass $(-0.27 \%$; $95 \%$ CI $-0.45 \%,-0.09 \% ; P<0.01)$ compared to controls [58]. This is supported by another meta-analysis including 12 studies in adolescents, where dairy intake was inversely associated with adiposity (average effect size $-0.26(-0.38$, $-0.14) P<0.0001)$ [59]. Though a lower risk of adiposity is associated with milk intake in adolescence, some studies find links between adiposity in childhood (age 7 years) and a high intake of milk protein in infancy and early childhood (below age 2 years) [60]. In Denmark, this has given rise to the recommendation that bovine milk should first be introduced when the infant is 1 year old.

Observational and intervention studies have examined the relationship between individual nutrients or milk (products), growth, and bone development. One of the proposed mechanisms behind the effects may be stimulation of growth factors such as IGF-I and insulin by elements in milk not present in other animal sources, e.g., meat. Hoppe and colleagues observed that consumption of $1.5 \mathrm{~L}$ skimmed milk daily in 24 8 -year-old boys for 1 week increased serum IGF-I by $19 \%(P$ $=0.001), \mathrm{s}-\mathrm{IGF}-\mathrm{I} / \mathrm{s}-\mathrm{IGFBP}-3$ by $13 \%(P<0.0001)$, and insulin doubled from $22.4 \pm 6.6$ to $45.0 \pm 25.8 \mathrm{pmol} / \mathrm{L}(P<0.01)$. They reported no effect of an equivalent protein intake from meat (250 g low fat meat/day) [39, 61]. In a subsequent study, the same research group found that casein increased IGF-I more than whey, and whey increased insulin more than casein, when both proteins were provided in amounts equivalent to 1.5 L skimmed milk [62]. These results suggest a cumulative effect of whey and casein on hormones important for growth, perhaps influenced by other elements in dairy products, and that consuming the complete product is required to maximize its effect.

Optimal bone mineralization may also be important for bone health and fracture risk in children, both with and without disease. In 100 girls 3-15 years old with recent fractured forearm, bone density as the total body, ultradistal radius, 33\% radius, lumbar spine, and hip trochanter was lower, and they were more likely to have osteopenia than age-matched girls with no fractures [63]. The 11-15-year-old girls with fractures reported a lower intake of dairy products at ages 6-10 years than controls, as did the 3-7-year-old girls at the time of fracture. Follow-up after 4 years indicated that a previous fracture, low total body BMD, low spine BMD, and high body weight were risk factors for fractures [64].

Evidence from several observational and prospective studies suggests that a high consumption of dairy products, especially milk, cheese, and yoghurt, is synonymous with better bone health. Intervention studies have subsequently investigated the effect of dairy supplementation on bone health during several stages of life. A systematic literature review of controlled trials assessing the effect of dairy product consumption on height and BMC in children concluded that supplementing the usual diet with dairy products increases BMC, especially in cases where the diet is poor in nutrients due to a high intake of fast foods [65]. Thus, bone mineralization appears to benefit from increased intake of dairy products, possibly mainly in children with a low baseline intake of calcium [66], although many of these studies providing the evidence are relatively short term ( 0.5 to 2 years). In this regards, more long-term studies are needed to evaluate whether increasing milk intake has long-term positive consequences for bone health and reduced fracture rates.

Dietary guidelines in several countries recommend milk intake during childhood, but there is no universal agreement on the optimal amount and if specific recommendations are required based on gender and age.

\section{Impact of dairy matrix on bone health and fracture risk-epidemiological evidence}

A meta-analysis of observational studies reported that cheese intake was associated with reduced risk of CVD [29, 67]. Randomised controlled studies have demonstrated improvements in bone mineral density and bone metabolism with dairy food supplementation [68-70]. Especially cheese, with a 6-fold higher calcium content than other dairy products, is shown to increase cortical thickness of the tibia and total mineral density among 195 girls [67]. However, no RCT (possibly 
due to shortness of study length) has yet found the risk of bone fracture to be reduced by dairy food supplementation.

A recent meta-analysis of observational studies of vegan/ vegetarian diets on bone health reported that a diet free of dairy products was associated with lower BMD at the femoral neck and lumbar spine and higher incidence of fractures in adults [71]. Two case-control studies including infants (1020 months old), children, adolescents, and young adults (up to 20 years) found impaired bone strength and higher fracture risk among those not consuming dairy products [72, 73]. However, evidence for a positive association between dairy food consumption and fracture risk reduction is inconsistent, possibly due to methodological differences in study design $[74,75]$. Issues include lack of consistency in which dairy foods are included in analyses, number, timing, and quality of dietary assessments, and validation of fractures.

More recent prospective studies have been designed specifically for bone related outcomes, so anti-fracture efficacy, if demonstrated, can be supported by mechanistic changes to bone. This is the case with an intervention finding consumption of calcium and vitamin $\mathrm{D}_{3}$-fortified dairy products for 12 months in 101 postmenopausal women decreased serum osteocalcin and PTH concentrations, and increased IGF-I; all indicators of reduced bone breakdown. This was confirmed by higher BMD observed in the fortified dairy product group at all investigated sites compared to those provided calcium supplements only, and control [76].

Comparing rates of fracture risk to dietary intake of calcium is inconclusive. Dietary calcium intake is high in Scandinavia, but these countries also report some of the highest rates of fracture, while very low risks of fracture is observed in Croatia with an equally high dietary calcium intake, and South American countries where calcium intakes are low $[77,78]$.

Epidemiological studies investigating the association of dairy intake with musculoskeletal health assess dietary habits in various ways. We need to consider how well the collected data reflect actual intake, and whether the data collection is appropriate for relating intake of dairy to a specific health outcome (Fig. 1).

Identifying habitual diet intake is problematic, in that dietary patterns change over time and it may be necessary to collect data at multiple time points to capture a good representation of habitual diet. Moreover, difficulties arise in defining habitual intake. The British National Diet and Nutrition Survey reported differences between genders in general dietary intake, and throughout the lifespan, where, in relation to dairy intake, females especially during adolescence reported a reduction in dairy (mainly milk) intake [79]. In the Danish National Diet and Nutrition Survey, the differences in nutrient intake, though not as large, are still present [80]. This may contribute to why results from observational studies using different time points of dietary assessment have inconsistent results $[74,81]$.

Another question is, at which life stages the greatest benefits of dairy consumption on bone is exerted? When measuring bone strength and fracture risk among the elderly, it may not be relevant to record dietary intake 5 years retrospectively while PBM, a major determinant of fracture risk in later life, occurred during adolescence or early adulthood. On the other hand, bone mass continues to remodel by resorption and formation throughout life, making it possible to slow the natural reduction in BMC, but there is a lack of studies reporting on this effect.

Foods classified as dairy in analyses of dairy intake differ between studies and countries, making it difficult to compare data. For example, the British National Diet and Nutrition Survey includes desserts, even some of which do not contain dairy, when summing dairy intake, while this is not the case in Denmark [79, 80]. Definitions in observational studies lack consistency, where for example cream and ice cream are often included but may be processed to such a degree that the product is no longer comparable to other dairy products, yet is still included [81]. Meta-analyses of observational studies potentially carry the risk of bias due to the assumption of serving sizes being equal, though they also differ substantially between countries [56]. This is the case in a newly published meta-analysis where the effects of cheese and yoghurt consumption from a Swedish and a US population are included in the same analyses, although consumption of cheese is twice as high and yoghurt is more than 40 times higher in the Swedish compared to the US population [74, 75, 81]. The same observational study reports increased fracture risk and a $2 \%$ increased mortality with a higher milk intake, but fails to draw attention to a reduction of $10 \%$ in risk of fracture with increased cheese and fermented dairy intake [75]. These inconsistencies underline the challenges in interpreting data from epidemiological studies and that the different types of dairy exert effects that may not be directly comparable.

\section{Protein quality and dairy matrix effects on skeletal muscle}

Skeletal muscle tissue exerts force onto ligaments and bones to allow functional capacity and personal autonomy. Over the last decade, more and more information has been generated on the existence of muscle-bone cross-talk. Mechanical loading is the key mechanism that links both tissues, with cross-talk being made possible by the production and release of growth factors and myokines from skeletal muscle fibers and osteokines secreted by osteoblasts and osteocytes [82]. Bone and muscle health affect each other through the secretion of myokines such as myostatin, irisin, interleukin (IL)-6, IL-7, IL-15, IGF-1, fibroblast growth factor (FGF)-2, and $\beta$ aminoisobutyric acid and through bone-derived factors 
including FGF23, prostaglandin E2, transforming growth factor $\beta$, osteocalcin, and sclerostin [83]. This tissue cross-talk ensures proper alignment between tissue remodeling and, as such, represents a key factor in maintaining bone and muscle health. In line, common pathways are likely responsible for the loss of bone and muscle mass in with aging in both health and disease [84].

To maintain skeletal muscle mass and quality, muscle protein is constantly being synthesized and broken down, with a turnover rate of about $1-2 \%$ per day. The rate of skeletal muscle protein synthesis is regulated by two main anabolic stimuli, food intake and physical activity. Food intake, and more specific protein ingestion, can directly elevate muscle protein synthesis rates by increasing the level of circulating amino acids, with leucine being of particular relevance. The post-prandial rise in muscle protein synthesis rate is regulated on various levels from protein digestion, amino acid absorption, plasma amino acid availability, hormonal response, postprandial perfusion, amino acid-induced anabolic signaling, and myofibrillar protein synthesis. Ingestion of a meal-like amount of dietary protein $(\sim 20 \mathrm{~g})$ elevates muscle protein synthesis rates for several hours following ingestion, resulting in net muscle protein accretion [85]. A substantial part of the ingested protein-derived amino acids are taken up and directly used to support the post-prandial rise in muscle protein synthesis rate following ingestion of a single bolus of protein. The dietary protein-derived amino acids present as strong signaling molecules and act as direct precursors for de novo muscle protein synthesis [86]. In short, ingestion of a single meal-like amount of protein allows $\sim 55 \%$ of the protein-derived amino acids to become available in circulation, thereby improving whole-body protein balance. Approximately 20\% of the protein-derived plasma amino acids will be incorporated in de novo synthesized skeletal muscle tissue during a 5-h post-prandial period [86], thereby stimulating muscle protein synthesis rates and providing precursors for de novo muscle protein. Post-prandial protein handling and the post-prandial muscle protein synthetic response to protein ingestion are modulated by numerous variables, including the amount, type, and amino acid composition of the protein ingested, as well as the matrix of the food in which the protein is provided. Ingestion of casein hydrolysate, compared to intact casein, has been shown to accelerate amino acid digestion and absorption from the gut with $27 \pm 6 \%$ more dietary derived phenylalanine appearing in the circulation, which tended to further increase post-prandial muscle protein synthesis rates [87]. Ingestion of whey results in a greater post-prandial rise in muscle protein synthesis rate when compared to the ingestion of intact or hydrolyzed casein, which may be attributed to the rapid digestion and high leucine content of whey protein [88]. Ingestion of beef results in a lower availability of phenylalanine than ingestion of milk during the early postprandial phase, but there were no significant differences in myofibrillar protein synthesis rate throughout a 5 -h postprandial period [89]. No effect of the co-ingestion of carbohydrate with protein on post-prandial muscle protein synthesis has been observed [90, 91]. Coingestion of milk fat with milk protein seems to delay the early release of dietary protein-derived phenylalanine, but this does not impair postprandial muscle protein synthesis rates [92].

A recent paper summarized the skeletal muscle protein synthetic response to the ingestion of plant- compared to animal-based protein consumption [93]. The review concluded that most studies indicate that plant-based protein sources do not have the same capacity to stimulate muscle protein synthesis upon ingestion when compared to the ingestion of animal-based proteins. This has been attributed to the relative low essential amino acid content, relative low leucine content, and shortage of specific amino acids such as lysine and methionine in plant-based proteins. However, only few plantbased proteins, such as soy and wheat, have actually been assessed for their in vivo anabolic properties. To compensate for the lesser anabolic response to plant-based protein feeding, more protein can be ingested. However, an increased intake of plant-based protein may increase the risk of the diet becoming less varied and will lower the intake of other essential nutrients or consuming more energy than needed, with the potential for accretion of fat mass as a consequence. Another strategy to compensate for the lower anabolic response to plant-based
Fig. 1 Dairy matrix, more than the sum of its nutrients. $\mathrm{Ca}$, calcium; MFG, milk fat globule; MFGM, milk fat globule membrane; P, phosphate; SCFA, short-chain fatty acids; UHT, ultra-high temperature processing

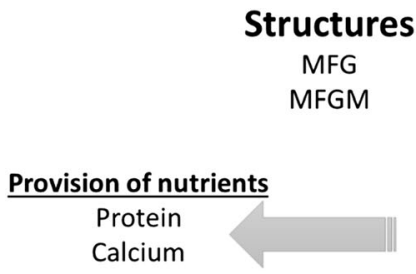

\section{Composition}

Protein

(Whey, casein, fragments)

Minerals e.g. Ca, $\mathrm{P}$

Butter

Ice-cream

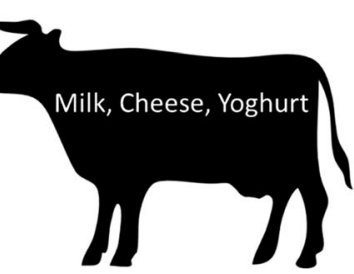

Processing

Fermentation

Cultures used Additives

\section{Production \\ Fortification \\ UHT}

Access to nutrients Absorption Transportation Gut microbiota

$\begin{array}{cc}\text { Form } & \text { Preparation } \\ \text { Solid } & \text { Heating } \\ \text { Gel } & \text { Melting } \\ \text { Liquid } & \text { Cooking }\end{array}$




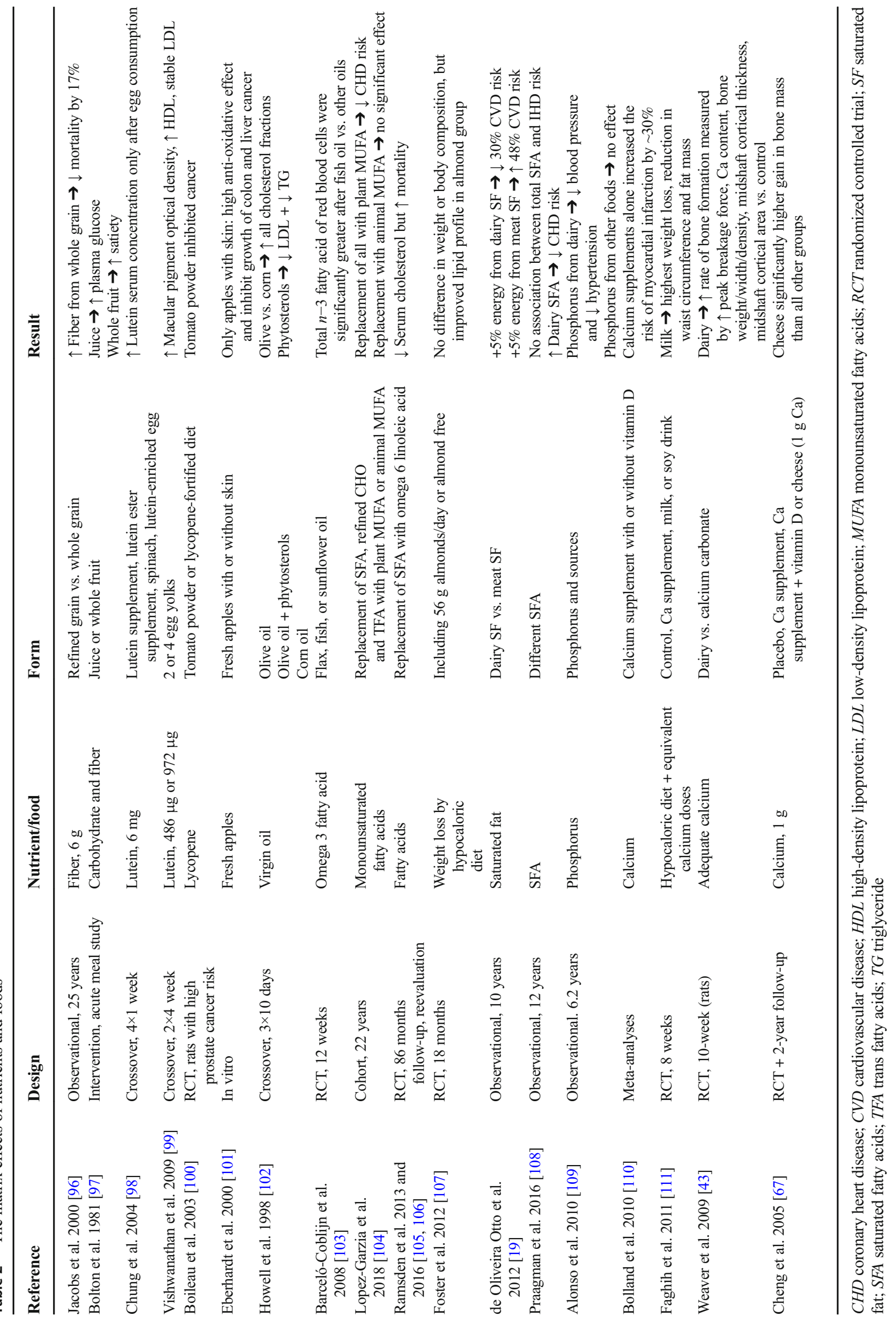


protein ingestion is fortification of plant-based proteins with specific amino acids. For example, co-ingestion of leucine has been shown to further increase postprandial muscle protein synthesis rates [94]. Addition of specific amino acids to vegetable protein sources may improve their otherwise suboptimal amino acid profile, increasing the anabolic effect. Another, more practical strategy would be the consumption of blends of different plant-based proteins, where some proteins low in a certain amino acid will compensate for other proteins low in other amino acids. The latter directly refers to the general dietary recommendation to consume a diet with a large variety of grains, legumes, and nuts. This further underlines the relevance of the consumption of different foods in meals providing the required nutrients derived from different sources.

Furthermore, non-food factors such as food preparation, mastication, body position, habitual protein intake, physical activity, and body composition are all factors that can influence post-prandial protein handling. Physical activity plays a large role in increasing sensitivity for up to 48 hours post-exercise, and inactivity, even short term, induces anabolic resistance and causes rapid muscle loss [95].

A simple recommendation to optimize the post-prandial stimulation of muscle protein synthesis in a healthy population is to consume at least three main meals, each providing $20 \mathrm{~g}$ of high-quality protein, spread throughout the day and the consumption of a protein-rich snack in the evening prior to sleep. A physically active lifestyle is required to ensure that skeletal muscle tissue remains sensitive to the anabolic properties of protein ingestion. Anabolic sensitivity is required to maintain skeletal muscle mass and strength and, as such, to preserve functional performance and autonomy. The latter are key to the muscle-bone unit, where constant cross-talk via growth factors, myokines, and osteokines lies at the basis of maintaining both bone and muscle health.

\section{Nutrition from a holistic point of view: we eat food not nutrients}

We do not eat nutrients, we eat food. We eat foods in dishes, we eat these dishes as meals, and these meals are part of dietary patterns, which may determine the overall health effects of what is ingested.

Historically, investigations have focused on single nutrients and the effects they exert on a single signal, molecule, or even single nucleotide polymorphisms. Findings have then been translated into nutritional advice. This has been useful in avoiding and treating deficiencies, but the approach has severe limitations in the development or prevention of non-communicable diseases globally.
Foods are more than the sum of the nutrients they contain. Effects differ according to their physio-chemical structurethe matrix - of the food. This is true for all the foods due to their complexity, but also to their specific composition and nutritional environment (for example, the diversity of dairy fatty acids), to the presence of "minor" micro-constituents which can play a major role, or as a consequence of processing.

The influence of different nutrients on biomarkers of disease risk has been investigated in both observational and interventional studies (Table 2). Effects may differ depending on the form or presence of other nutrients. This is the case for isolated fibers compared to the whole grains which contain, for instance, lignans or arabinoxylans [96]; for carbohydrates such as fructose whose effects differ if consumed alone or as part of a fruit [97]; for oleic acid where effects differ for olive oil or from fatty pork [112]; for calcium in spinach or in milk [113]; for saturated fatty acids in meat or in cheese, which are

Table 3 Research gaps, recommendations, and future strategies

Research gaps

To what extent do dietary habits early in life influence later risk of fractures?

Increasingly interesting due to poor dietary habits, low intake of micronutrients among adolescents in combination with low level of physical activity (e.g., 20-30\% of UK young females have intakes of magnesium and calcium below the recommended minimum level of intake)

Quality of foods or its ingredients should refer to their capacity to serve a specific function or provide specific health benefits. More in vivo human studies are needed to assess food quality. Recommendations

More randomized controlled studies, with a solid methodological approach, to investigate the effect of plant-based foods and beverages are needed.

When evaluating quality of foods, the goal must be kept in mind. What effect/quality of a product do we wish for or desire?

To show the metabolic effects of new products takes longer time than the product development; therefore, we need to evaluate the effect of new products on bone and muscle metabolism with attention to detail and caution.

Pitfalls when interpreting data and comparing results; differences in methodology and simple things as serving sizes, groups of foods, content varies from country to country and between studies.

Future strategies

Anabolic effects of protein; we need both leucine and other amino acids in sufficient amounts.

Can leucine supplementation increase the anabolic effect in people with low intake and increased needs, e.g., elderly and ill or in people with no or minimal intake of animal-based protein, i.e., vegan and vegetarian?

Future studies should investigate the effect of early dietary habits on later risk of fractures by including long-term and family studies.

Studies investigating the digestion and absorption of different protein sources in children, adolescents, adults, and the old; also during specific life phases where higher nutritional demands may exist.

Standardization of study methods and dietary assessment to make results more comparable and the outcome of meta-analyses relevant.

Public dissemination of the differences in nutritional profile mean that plant-based beverages are not comparable with dairy products and should not be portrayed as such. 
associated with opposite effects on cardiovascular risk in epidemiological studies [5]; and for calcium, where dairy products showed higher effect on bone mass and weight loss than calcium supplements $[43,67,111]$. The huge variability of nutrients within foods, and variability due to the food they are in and the meal it is a part of, and the possibility of variations in effect from consumer to consumer need to be acknowledged and explored.

\section{Wrapping up the workshop}

The research gaps, recommendations, and future strategies identified during the workshop are presented in Table 3. Diet is changing rapidly, including increasing intake of new plantbased products motivated by environmental considerations, increased intake of carbonated energy drinks, and decreasing physical activity, e.g., the use of motorized means of transportation. These lifestyle changes may have a detrimental effect on PBM and muscle development, during growth, leading eventually to increased risk of bone fractures, diabetes, and obesity.

The average age of the population globally is increasing, and an older population needs a more nutritionally dense diet. Meeting increasing demands-both for foods and for nutrients - raises sustainability issues. Increasing the amount of plant-based foods in our diet is perhaps inevitably a consequence, but the nutritional sufficiency and effects on health of plant-based alternatives to animal-derived foods need to be investigated relative to the effect of the nutrients such as protein and calcium predominantly obtained from these animalbased foods.

In conclusion, available evidence suggests that calcium from dairy products, in particular from fermented dairy and cheese, exerts positive effects on bone turnover, beyond those to be expected on the basis of the calcium content itself, with no adverse effects on cardiometabolic health. There is a greater array of food matrixes, also in foods other than dairy, than previously observed. Diet is complex and is more than simply the sum of its nutrients. The matrix effect may, to some extent, explain the discrepancy between observational data and data from RCTs. We must revisit the methodology and interpretation of epidemiological studies, and a holistic approach is essential. We must recognize the possibility of matrix effects from all foods and include this in the design of future studies. We propose a new dietary approach to investigate health benefits of foods, beyond just nutrients, and to consider foods as opposed to nutrients when defining guidelines on dietary intake.

Acknowledgments A.A. arranged the workshop and invited the participating scientists. N.R.W.G. drafted the manuscript based on summaries and presentations delivered by the participants of the workshop. All authors made contributions to a number of draft versions, and all approved the final manuscript. A.A. is the guarantor of the manuscript.

\section{Compliance with ethical standards}

Disclosure of financial conflicts of interest The meeting of the Working Group was funded by the European Society for Clinical and Economic Aspects of Osteoporosis, Osteoarthritis and Musculoskeletal Diseases (ESCEO), a Belgian not-for-profit organization and held in Geneva, Switzerland on June 18, 2019. The Working Group was entirely funded by the ESCEO. The ESCEO receives Unrestricted Educational Grants, to support its educational and scientific activities, from non-governmental organizations, not-for-profit organizations, and non-commercial and corporate partners. The choice of topics, participants, content, and agenda of the Working Groups as well as the writing, editing, submission, and publication processes of the manuscript are under the sole responsibility of the ESCEO, without any influence from third parties.

N.R.W.G. has received salary from ESCEO for acting as a rapporteur during the workshop and for preparing the manuscript. N.R.W.G. has received research funding from Danish Dairy Research Foundation.

C.M. has received research funding from Danish Dairy Research Foundation, ARLA Food, ARLA Food for Health, and Chr. Hansen.

Y.M. and G.M. have received research funding from Friesland Foods Hellas and FrieslandCampina BV.

L.J.C.v.L. has received research grants, consulting fees, speaking honoraria, or a combination of these, from FrieslandCampina, Nutricia, and PepsiCo.

J.-M.L. and Nutrition Department of Institut Pasteur de Lille collaborates with Lactalis, Syndifrais, Candia, and CNIEL (Centre National Interprofessionnel de l'Economie Laitière). J.-M.L. is member of the Scientific Advisory Board of Institut Olga Triballat, ENSA (European Natural Soyfoods Association), OCHA (Observatoire CNIEL des Habitudes Alimentaires), FICT (Fédération Interprofessionnelle des Charcutiers Traiteurs), and APRIFEL (Agence des Fruits et Légumes frais).

I.G. has received dairy and health research funding from UK BBSRC (Biotechnology and Biological Sciences Research Council), UK MRC (Medical Research Council), GB Dairy Council, UK Agriculture and Horticulture Development Board Dairy (AHDB Dairy), The Dutch Dairy Association, The Global Dairy Platform, The Barham Foundation Trust, and various companies. Is or recently has been a member of UK Food Standards Agency Advisory Committee; Scientific Panel Estonian Biocompetance Centre of Healthy Dairy Products (BioCC); Consultant to the GB Dairy Council on Fats in Dairy Products and Cardiometabolic Disease.

A.A. receives payment as Associate Editor of The American Journal of Clinical Nutrition and as a member of the Editorial Committee of Annual Review of Nutrition.

A.A. is advisor to or a member of advisory boards for a number of food and pharmaceutical producers: BioCare Copenhagen, DK; Dutch Beer Institute, NL; Gelesis, USA; Groupe Éthique et Santé, France; McCain Foods Limited, USA; Novo Nordisk, DK; Ritual, USA; Saniona, DK; Weight Watchers, USA.

A.A.'s recent research at the University of Copenhagen, Denmark, has received funding via unrestricted grants from or contracts with Danish Dairy Foundation, Global Dairy Platform, European Milk Forum, and Gelesis AS, USA.

A.A. is recipient of honoraria as speaker for a wide range of Danish and international concerns and receives royalties from textbooks, and from popular diet and cookery books.

A.A. is co-inventor of a number of patents, including Methods of inducing weight loss, treating obesity and preventing weight gain (licensee Gelesis, USA) and Biomarkers for predicting degree of weight loss (licensee Nestec SA, CH), owned by the University of Copenhagen, in accordance with Danish law.

A.A. is co-founder and co-owner of the University of Copenhagen spin-out companies Mobile Fitness A/S, Personalized Weight 
Management Research Consortium ApS (Gluco-diet.dk), and Flaxslim ApS, where he is also member of the board.

A.A. is not advocate or activist for specific diets, and is not strongly committed to any specific diet, e.g.. veganism, Atkins diet, gluten-free diet, high animal protein diet, or dietary supplements.

The remaining authors reported no conflicts of interest related to the present work.

Open Access This article is licensed under a Creative Commons Attribution-NonCommercial 4.0 International License, which permits any non-commercial use, sharing, adaptation, distribution and reproduction in any medium or format, as long as you give appropriate credit to the original author(s) and the source, provide a link to the Creative Commons licence, and indicate if changes were made. The images or other third party material in this article are included in the article's Creative Commons licence, unless indicated otherwise in a credit line to the material. If material is not included in the article's Creative Commons licence and your intended use is not permitted by statutory regulation or exceeds the permitted use, you will need to obtain permission directly from the copyright holder. To view a copy of this licence, visit http:// creativecommons.org/licenses/by-nc/4.0/.

\section{References}

1. Council N (2014) Nordic Nutrition Recommendations 2012: Integrating Nutrition and Physical Activity.

2. Health UDo, Services H (2017) Dietary guidelines for Americans 2015-2020. Skyhorse Publishing Inc.

3. Contento I, Balch G, Bronner Y, Paige D, Gross S, Bisignani L, Lytle L, Maloney S, White S, Olson C (1995) The effectiveness of nutrition education and implications for nutrition education policy, programs, and research: a review of research. J nutr educ 27

4. Organization WH (2018) Draft guidelines on saturated fatty acid and trans-fatty acid intake for adults and children. WHO https:// extranet who int/dataform/upload/surveys/666752/files/Draft\% 20WHO\% 20SFA-TFA\% 20guidelines 04052018\% 20Public\% 20Consultation (1) pdf

5. Astrup A, Bertram HC, Bonjour J-P, de Groot LC, de Oliveira Otto MC, Feeney EL, Garg ML, Givens I, Kok FJ, Krauss RM, Lamarche B, Lecerf J-M, Legrand P, McKinley M, Micha R, Michalski M-C, Mozaffarian D, Soedamah-Muthu SS (2019) WHO draft guidelines on dietary saturated and trans fatty acids: time for a new approach? BMJ 366:14137. https://doi.org/10.1136/ bmj.14137

6. Grosicki GJ, Fielding RA, Lustgarten MS (2018) Gut microbiota contribute to age-related changes in skeletal muscle size, composition, and function: biological basis for a gut-muscle axis. Calcif tissue int 102(4):433-442

7. Rizzoli R (2019) Nutritional influence on bone: role of gut microbiota. Aging clin exp res:1-9

8. Nilsson A, Sundh D, Bäckhed F, Lorentzon M (2018) Lactobacillus reuteri reduces bone loss in older women with low bone mineral density: a randomized, placebo-controlled, doubleblind, clinical trial. J intern med 284(3):307-317

9. Curtis EM, Moon RJ, Harvey NC, Cooper C (2017) Reprint of: the impact of fragility fracture and approaches to osteoporosis risk assessment worldwide. Int $j$ orthop trauma nurs 26:7-17

10. Oden A, McCloskey EV, Kanis JA, Harvey NC, Johansson H (2015) Burden of high fracture probability worldwide: secular increases 2010-2040. Osteoporos Int 26(9):2243-2248

11. Weaver C, Gordon C, Janz K, Kalkwarf H, Lappe JM, Lewis R, O'Karma M, Wallace T, Zemel B (2016) The National Osteoporosis Foundation's position statement on peak bone mass development and lifestyle factors: a systematic review and implementation recommendations. Osteoporos int 27(4):1281-1386

12. Cruz-Jentoft AJ, Bahat G, Bauer J, Boirie Y, Bruyère $\mathrm{O}$, Cederholm T, Cooper C, Landi F, Rolland Y, Sayer AA (2018) Sarcopenia: revised European consensus on definition and diagnosis. Age ageing 48(1):16-31

13. Shafiee G, Keshtkar A, Soltani A, Ahadi Z, Larijani B, Heshmat R (2017) Prevalence of sarcopenia in the world: a systematic review and meta-analysis of general population studies. J Diabetes Metab Disord 16(1):21

14. Hunter GR, Singh H, Carter SJ, Bryan DR, Fisher G (2019) Sarcopenia and its implications for metabolic health. J obes 2019

15. Cermak NM, Res PT, de Groot LC, Saris WH, Van Loon LJ (2012) Protein supplementation augments the adaptive response of skeletal muscle to resistance-type exercise training: a metaanalysis. The Am j clin nutr 96(6): 1454-1464

16. Tang JE, Moore DR, Kujbida GW, Tarnopolsky MA, Phillips SM (2009) Ingestion of whey hydrolysate, casein, or soy protein isolate: effects on mixed muscle protein synthesis at rest and following resistance exercise in young men. J appl physiol 107(3):987992

17. Durosier-Izart C, Biver E, Merminod F, van Rietbergen B, Chevalley T, Herrmann FR, Ferrari SL, Rizzoli R (2017) Peripheral skeleton bone strength is positively correlated with total and dairy protein intakes in healthy postmenopausal women. The Am j clin nutr 105(2):513-525

18. Rizzoli R (2014) Dairy products, yogurts, and bone health. The Am j clin nutr 99(5):1256S-1262S

19. de Oliveira Otto MC, Mozaffarian D, Kromhout D, Bertoni AG, Sibley CT, Jacobs DR Jr, Nettleton JA (2012) Dietary intake of saturated fat by food source and incident cardiovascular disease: the Multi-Ethnic Study of Atherosclerosis. The Am j clin nutr 96(2):397-404

20. Weinberg LG, Berner LA, Groves JE (2004) Nutrient contributions of dairy foods in the United States, Continuing Survey of Food Intakes by Individuals, 1994-1996, 1998. J Am Diet Assoc 104(6):895-902

21. EFSA Panel on Dietetic Products N, Allergies (2010) Scientific opinion on establishing food-based dietary guidelines. EFSA Journal 8 (3):1460

22. Eckel RH, Jakicic JM, Ard JD, De Jesus JM, Miller NH, Hubbard VS, Lee I-M, Lichtenstein AH, Loria CM, Millen BE (2014) 2013 AHA/ACC guideline on lifestyle management to reduce cardiovascular risk: a report of the American College of Cardiology/ American Heart Association Task Force on Practice Guidelines J Am Coll Cardiol 63 (25_PA)

23. Chowdhury R, Warnakula S, Kunutsor S, Crowe F, Ward HA, Johnson L, Franco OH, Butterworth AS, Forouhi NG, Thompson SG (2014) Association of dietary, circulating, and supplement fatty acids with coronary risk: a systematic review and meta-analysis. Ann int med 160(6):398-406

24. Siri-Tarino PW, Sun Q, Hu FB, Krauss RM (2010) Saturated fatty acids and risk of coronary heart disease: modulation by replacement nutrients. Curr atheroscler rep 12(6):384-390

25. De Souza RJ, Mente A, Maroleanu A, Cozma AI, Ha V, Kishibe T, Uleryk E, Budylowski P, Schünemann H, Beyene J (2015) Intake of saturated and trans unsaturated fatty acids and risk of all cause mortality, cardiovascular disease, and type 2 diabetes: systematic review and meta-analysis of observational studies. Bmj 351: h3978

26. Pichler G, Amigo N, Tellez-Plaza M, Pardo-Cea M, DominguezLucas A, Marrachelli V, Monleon D, Martin-Escudero JC, Ascaso J, Chaves F (2018) LDL particle size and composition and incident cardiovascular disease in a South-European population: The Hortega-Liposcale Follow-up Study. Int j cardiol 264:172-178 
27. Thorning TK, Bertram HC, Bonjour J-P, De Groot L, Dupont D, Feeney E, Ipsen R, Lecerf JM, Mackie A, McKinley MC (2017) Whole dairy matrix or single nutrients in assessment of health effects: current evidence and knowledge gaps. The Am j clin nutr 105(5):1033-1045

28. Astrup A (2014) Yogurt and dairy product consumption to prevent cardiometabolic diseases: epidemiologic and experimental studies. The Am j clin nutr 99(5):1235S-1242S

29. Guo J, Astrup A, Lovegrove JA, Gijsbers L, Givens DI, Soedamah-Muthu SS (2017) Milk and dairy consumption and risk of cardiovascular diseases and all-cause mortality: doseresponse meta-analysis of prospective cohort studies. Springer

30. Abargouei AS, Janghorbani M, Salehi-Marzijarani M, Esmaillzadeh A (2012) Effect of dairy consumption on weight and body composition in adults: a systematic review and metaanalysis of randomized controlled clinical trials. Int j obes 36(12): 1485-1493

31. Morency M-E, Birken CS, Lebovic G, Chen Y, L' Abbé M, Lee GJ, Maguire JL, Collaboration TK (2017) Association between noncow milk beverage consumption and childhood height. The Am j clin nutr 106 (2):597-602

32. Gui J-C, Brašić J, Liu X-D, Gong G-Y, Zhang G-M, Liu C-J, Gao G-Q (2012) Bone mineral density in postmenopausal Chinese women treated with calcium fortification in soymilk and cow's milk. Osteoporos Int 23(5):1563-1570

33. Commission E (2013) Policy instruments for the dairy sectormilk and milk products. Official Journal of the European Union (L347/814)

34. Food D Frida Food data. DTU Fødevareinstituttet. https://frida. fooddata.dk/

35. Callaway J (2004) Hempseed as a nutritional resource: an overview. Euphytica 140(1-2):65-72

36. Scholz-Ahrens KE, Ahrens F, Barth CA (2019) Nutritional and health attributes of milk and milk imitations. Eur j nutr:1-16

37. Gorissen SH, Crombag JJ, Senden JM, Waterval WH, Bierau J, Verdijk LB, van Loon LJ (2018) Protein content and amino acid composition of commercially available plant-based protein isolates. Amino acids 50(12):1685-1695

38. Litmanovitz I, Davidson K, Eliakim A, Regev RH, Dolfin T, Arnon S, Bar-Yoseph F, Goren A, Lifshitz Y, Nemet D (2013) High beta-palmitate formula and bone strength in term infants: a randomized, double-blind, controlled trial. Calcif tissue int 92(1): $35-41$

39. Hoppe C, Mølgaard C, Juul A, Michaelsen K (2004) High intakes of skimmed milk, but not meat, increase serum IGF-I and IGFBP3 in eight-year-old boys. Eur J Clin Nutr 58(9):1211-1216

40. Heaney RP, Dowell MS, Rafferty K, Bierman J (2000) Bioavailability of the calcium in fortified soy imitation milk, with some observations on method. The Am J Clin Nutr 71(5):11661169. https://doi.org/10.1093/ajcn/71.5.1166

41. Zhao Y, Martin BR, Weaver CM (2005) Calcium bioavailability of calcium carbonate fortified soymilk is equivalent to cow's milk in young women. The J nutr 135(10):2379-2382

42. Tang AL, Walker KZ, Wilcox G, Strauss BJ, Ashton JF, Stojanovska L (2010) Calcium absorption in Australian osteopenic postmenopausal women: an acute comparative study of fortified soymilk to cows. Asia Pac j clin nutr 19(2):243-249

43. Weaver CM, Janle E, Martin B, Browne S, Guiden H, Lachcik P, Lee WH (2009) Dairy versus calcium carbonate in promoting peak bone mass and bone maintenance during subsequent calcium deficiency. J Bone Miner Res 24(8):1411-1419

44. Koletzko B, Goulet O, Hunt J, Krohn K, Shamir R, Group PNGW (2005) 1. Guidelines on paediatric parenteral nutrition of the European Society of Paediatric Gastroenterology, Hepatology and Nutrition (ESPGHAN) and the European Society for Clinical Nutrition and Metabolism (ESPEN), supported by the
European Society of Paediatric Research (ESPR). J pediatr gastroenterol nutr 41:S1-S4

45. Heaney RP (1991) Calcium intake in the osteoporotic fracture context: introduction. The Am j clin nutr 54(1):242S-244S

46. Ellis D, Lieb J (2015) Hyperoxaluria and genitourinary disorders in children ingesting almond milk products. The Journal of pediatrics 167(5):1155-1158

47. Biver E, Durosier-Izart C, Merminod F, Chevalley T, van Rietbergen B, Ferrari SL, Rizzoli R (2018) Fermented dairy products consumption is associated with attenuated cortical bone loss independently of total calcium, protein, and energy intakes in healthy postmenopausal women. Osteoporos Int 29(8):17711782

48. Cheung ALTF, Wilcox G, Walker KZ, Shah NP, Strauss B, Ashton JF, Stojanovska L (2011) Fermentation of calcium-fortified soya milk does not appear to enhance acute calcium absorption in osteopenic post-menopausal women. Br j nutr 105(2):282-286

49. Rizzoli R, Biver E (2018) Effects of fermented milk products on bone. Calcif tissue int 102(4):489-500

50. Heaney RP, Rafferty K (2006) The settling problem in calciumfortified soybean drinks. J Acad Nutr Diet 106(11):1753

51. Klibanski A, Adams-Campbell L, Bassford TL, Blair SN, Boden SD, Dickersin K, Gifford DR, Glasse L, Goldring SR, Hruska K (2001) Osteoporosis prevention, diagnosis, and therapy. J Am Med Assoc 285(6):785-795

52. Laine CM, Laine T (2013) Diagnosis of osteoporosis in children and adolescents. European endocrinology 9(2):141-144

53. Hoppe C, Mølgaard C, Michaelsen KF (2006) Cow's milk and linear growth in industrialized and developing countries. Annu Rev Nutr 26:131-173

54. Bogin B (1998) Milk and human development: an essay on the "milk hypothesis".

55. Orr JB (1928) Influence of amount of milk consumption on the rate of growth of school children. Br med j 1(3499):140-141

56. Dror DK, Allen LH (2014) Dairy product intake in children and adolescents in developed countries: trends, nutritional contribution, and a review of association with health outcomes. Nutr rev 72(2):68-81

57. de Beer H (2012) Dairy products and physical stature: a systematic review and meta-analysis of controlled trials. Econo Hum Biol 10(3):299-309

58. Kang K, Sotunde OF, Weiler HA (2019) Effects of milk and milkproduct consumption on growth among children and adolescents aged 6-18 years: a meta-analysis of randomized controlled trials. Adv Nutr 10(2):250-261

59. Dror D (2014) Dairy consumption and pre-school, school-age and adolescent obesity in developed countries: a systematic review and meta-analysis. Obes rev 15(6):516-527

60. Günther AL, Remer T, Kroke A, Buyken AE (2007) Early protein intake and later obesity risk: which protein sources at which time points throughout infancy and childhood are important for body mass index and body fat percentage at $7 \mathrm{y}$ of age? The Am $\mathrm{j}$ of clin nutr 86(6): 1765-1772

61. Hoppe C, Mølgaard C, Vaag A, Barkholt V, Michaelsen K (2005) High intakes of milk, but not meat, increase s-insulin and insulin resistance in 8-year-old boys. Eur J Clin Nutr 59(3):393-398

62. Hoppe C, Mølgaard C, Dalum C, Vaag A, Michaelsen KF (2009) Differential effects of casein versus whey on fasting plasma levels of insulin, IGF-1 and IGF-1/IGFBP-3: results from a randomized 7-day supplementation study in prepubertal boys. Eur J Clin Nutr 63(9):1076-1083

63. Goulding A, Cannan R, Williams S, Gold E, Taylor R, LewisBarned N (1998) Bone mineral density in girls with forearm fractures. J Bone Miner Res 13(1):143-148

64. Goulding A, Jones I, Taylor R, Manning P, Williams S (2000) More broken bones: a 4-year double cohort study of young girls 
with and without distal forearm fractures. J Bone Miner Res 15(10):2011-2018

65. de Lamas C, de Castro MJ, Gil-Campos M, Gil Á, Couce ML, Leis R (2018) Effects of dairy product consumption on height and bone mineral content in children: a systematic review of controlled trials. Adv Nutr 10(suppl_2):S88-S96

66. van den Heuvel EG, Steijns JM (2018) Dairy products and bone health: how strong is the scientific evidence? Nutr res rev 31(2): 164-178

67. Cheng S, Lyytikäinen A, Kröger H, Lamberg-Allardt C, Alén M, Koistinen A, Wang QJ, Suuriniemi M, Suominen H, Mahonen A (2005) Effects of calcium, dairy product, and vitamin D supplementation on bone mass accrual and body composition in 10-12y-old girls: a 2-y randomized trial. The Am j clin nutr 82(5):11151126

68. Cadogan J, Eastell R, Jones N, Barker ME (1997) Milk intake and bone mineral acquisition in adolescent girls: randomised, controlled intervention trial. Bmj 315(7118):1255-1260

69. Baran D, Sorensen A, Grimes J, Lew R, Karellas A, Johnson B, Roche J (1990) Dietary modification with dairy products for preventing vertebral bone loss in premenopausal women: a three-year prospective study. The J Clin Endocrinol Metab 70(1):264-270

70. Wadolowska L, Sobas K, Szczepanska J, Slowinska M, CzlapkaMatyasik M, Niedzwiedzka E (2013) Dairy products, dietary calcium and bone health: possibility of prevention of osteoporosis in women: the Polish experience. Nutrients 5(7):2684-2707

71. Iguacel I, Miguel-Berges ML, Gómez-Bruton A, Moreno LA, Julián C (2018) Veganism, vegetarianism, bone mineral density, and fracture risk: a systematic review and meta-analysis. Nutr rev 77(1):1-18

72. Konstantynowicz J, Nguyen T, Kaczmarski M, Jamiolkowski J, Piotrowska-Jastrzebska J, Seeman E (2007) Fractures during growth: potential role of a milk-free diet. Osteoporos int 18(12): 1601-1607

73. Dagnelie PC, Vergote FJ, van Staveren WA, van den Berg H, Dingjan P, Hautvast J (1990) High prevalence of rickets in infants on macrobiotic diets. The Am j clin nutr 51(2):202-208

74. Matía-Martín P, Torrego-Ellacuría M, Larrad-Sainz A, FernándezPérez C, Cuesta-Triana F, Rubio-Herrera MÁ (2018) Effects of milk and dairy products on the prevention of osteoporosis and osteoporotic fractures in Europeans and non-Hispanic Whites from North America: a systematic review and updated meta-analysis. Advances in Nutrition 10(suppl_2):S120-S143

75. Michaëlsson K, Wolk A, Langenskiöld S, Basu S, Lemming EW, Melhus H, Byberg L (2014) Milk intake and risk of mortality and fractures in women and men: cohort studies. Bmj 349:g6015

76. Manios Y, Moschonis G, Trovas G, Lyritis GP (2007) Changes in biochemical indexes of bone metabolism and bone mineral density after a 12-mo dietary intervention program: the Postmenopausal Health Study. The Am j clin nutr 86(3):781-789

77. Kanis JA, Oden A, McCloskey EV, Johansson H, Wahl DA, Cooper C (2012) A systematic review of hip fracture incidence and probability of fracture worldwide. Osteoporos int 23(9):2239 2256

78. Balk E, Adam G, Langberg V, Earley A, Clark P, Ebeling P, Mithal A, Rizzoli R, Zerbini C, Pierroz D (2017) Global dietary calcium intake among adults: a systematic review. Osteoporos Int 28(12): 3315-3324

79. Whitton C, Nicholson SK, Roberts C, Prynne CJ, Pot GK, Olson A, Fitt E, Cole D, Teucher B, Bates B (2011) National Diet and Nutrition Survey: UK food consumption and nutrient intakes from the first year of the rolling programme and comparisons with previous surveys. Br j nutr 106(12):1899-1914

80. Pedersen AN, Christensen T, Matthiessen J, Knudsen VK, Sørensen MR, Biltoft-Jensen AP, Hinsch H-J, Ygil KH, Kørup
K, Saxholt E (2015) Danskernes kostvaner 2011-2013. Danmarks Tekniske Universitet, DTU Fødevareinstituttet

81. Feskanich D, Meyer H, Fung T, Bischoff-Ferrari H, Willett W (2018) Milk and other dairy foods and risk of hip fracture in men and women. Osteoporos Int 29(2):385-396

82. Tagliaferri C, Wittrant Y, Davicco M-J, Walrand S, Coxam V (2015) Muscle and bone, two interconnected tissues. Ageing res rev 21:55-70

83. Li G, Zhang L, Wang D, AIQudsy L, Jiang JX, Xu H, Shang P (2019) Muscle-bone crosstalk and potential therapies for sarcoosteoporosis. J cell biochem

84. Reginster J-Y, Beaudart C, Buckinx F, Bruyère O (2016) Osteoporosis and sarcopenia: two diseases or one? Curr opin clin nutr metab care 19(1):31-36

85. Moore DR, Robinson MJ, Fry JL, Tang JE, Glover EI, Wilkinson SB, Prior T, Tarnopolsky MA, Phillips SM (2009) Ingested protein dose response of muscle and albumin protein synthesis after resistance exercise in young men. The Am j clin nutr 89(1):161168

86. Groen BB, Horstman AM, Hamer HM, De Haan M, Van Kranenburg J, Bierau J, Poeze M, Wodzig WK, Rasmussen BB, Van Loon LJ (2015) Post-prandial protein handling: you are what you just ate. PLoS One 10(11):e0141582

87. Koopman R, Crombach N, Gijsen AP, Walrand S, Fauquant J, Kies AK, Lemosquet S, Saris WH, Boirie Y, van Loon LJ (2009) Ingestion of a protein hydrolysate is accompanied by an accelerated in vivo digestion and absorption rate when compared with its intact protein. The Am j clin nutr 90(1):106-115

88. Pennings B, Boirie Y, Senden JM, Gijsen AP, Kuipers H, van Loon LJ (2011) Whey protein stimulates postprandial muscle protein accretion more effectively than do casein and casein hydrolysate in older men. The Am j clin nutr 93(5):997-1005

89. Burd NA, Gorissen SH, Van Vliet S, Snijders T, Van Loon LJ (2015) Differences in postprandial protein handling after beef compared with milk ingestion during postexercise recovery: a randomized controlled trial. The Am j clin nutr 102(4):828-836

90. Hamer HM, Wall BT, Kiskini A, de Lange A, Groen BB, Bakker JA, Gijsen AP, Verdijk LB, van Loon LJ (2013) Carbohydrate coingestion with protein does not further augment post-prandial muscle protein accretion in older men. Nutr metab 10(1):15

91. Gorissen SH, Burd NA, Hamer HM, Gijsen AP, Groen BB, Van Loon LJ (2014) Carbohydrate coingestion delays dietary protein digestion and absorption but does not modulate postprandial muscle protein accretion. The J Clin Endocrinol Metab 99(6):2250 2258

92. Gorissen SH, Burd NA, Kramer IF, van Kranenburg J, Gijsen AP, Rooyackers O, van Loon LJ (2017) Co-ingesting milk fat with micellar casein does not affect postprandial protein handling in healthy older men. Clin nutr 36(2):429-437

93. van Vliet S, Burd NA, van Loon LJ (2015) The skeletal muscle anabolic response to plant-versus animal-based protein consumption. The J nutr 145(9):1981-1991

94. Wall BT, Hamer HM, de Lange A, Kiskini A, Groen BB, Senden JM, Gijsen AP, Verdijk LB, van Loon LJ (2013) Leucine coingestion improves post-prandial muscle protein accretion in elderly men. Clin nutr 32(3):412-419

95. Wall BT, Dirks ML, Van Loon LJ (2013) Skeletal muscle atrophy during short-term disuse: implications for age-related sarcopenia. Ageing res rev 12(4):898-906

96. Jacobs DR Jr, Pereira MA, Meyer KA, Kushi LH (2000) Fiber from whole grains, but not refined grains, is inversely associated with all-cause mortality in older women: the Iowa women's health study. Journal of the American College of Nutrition 19(sup3): $326 \mathrm{~S}-330 \mathrm{~S}$ 
97. Bolton RP, Heaton KW, Burroughs LF (1981) The role of dietary fiber in satiety, glucose, and insulin: studies with fruit and fruit juice. The Am j clin nutr 34(2):211-217

98. Chung H-Y, Rasmussen HM, Johnson EJ (2004) Lutein bioavailability is higher from lutein-enriched eggs than from supplements and spinach in men. The J Nutr 134(8):1887-1893. https://doi.org/ $10.1093 / \mathrm{jn} / 134.8 .1887$

99. Vishwanathan R, Goodrow-Kotyla EF, Wooten BR, Wilson TA, Nicolosi RJ (2009) Consumption of 2 and 4 egg yolks/d for $5 \mathrm{wk}$ increases macular pigment concentrations in older adults with low macular pigment taking cholesterol-lowering statins. The Am j clin nutr 90(5):1272-1279

100. Boileau TW-M, Liao Z, Kim S, Lemeshow S, Erdman J, John W, Clinton SK (2003) Prostate carcinogenesis in N-methyl-Nnitrosourea (NMU)-testosterone-treated rats fed tomato powder, lycopene, or energy-restricted diets. JNCI: J Natl Cancer Inst 95(21):1578-1586. https://doi.org/10.1093/jnci/djg081

101. Eberhardt M, Lee C, Liu R (2000) Antioxidant activity of fresh apples. Nature 405:903-904

102. Howell TJ, MacDougall DE, Jones PJ (1998) Phytosterols partially explain differences in cholesterol metabolism caused by corn or olive oil feeding. J lipid res 39(4):892-900

103. Barceló-Coblijn G, Murphy EJ, Othman R, Moghadasian MH, Kashour T, Friel JK (2008) Flaxseed oil and fish-oil capsule consumption alters human red blood cell $\mathrm{n}-3$ fatty acid composition: a multiple-dosing trial comparing 2 sources of $n-3$ fatty acid. The Am J Clin Nutr 88(3):801-809. https://doi.org/10.1093/ajcn/88.3. 801

104. Lopez-Garcia E, Hagan KA, Fung TT, Hu FB, Rodríguez-Artalejo $\mathrm{F}$ (2018) Mediterranean diet and risk of frailty syndrome among women with type 2 diabetes. The Am j clin nutr 107(5):763-771

105. Ramsden CE, Zamora D, Leelarthaepin B, Majchrzak-Hong SF, Faurot KR, Suchindran CM, Ringel A, Davis JM, Hibbeln JR (2013) Use of dietary linoleic acid for secondary prevention of coronary heart disease and death: evaluation of recovered data from the Sydney Diet Heart Study and updated meta-analysis. Bmj 346:e8707

106. Ramsden CE, Zamora D, Majchrzak-Hong S, Faurot KR, Broste SK, Frantz RP, Davis JM, Ringel A, Suchindran CM, Hibbeln JR
(2016) Re-evaluation of the traditional diet-heart hypothesis: analysis of recovered data from Minnesota Coronary Experiment (1968-73). bmj 353:i1246

107. Foster GD, Shantz KL, Vander Veur SS, Oliver TL, Lent MR, Virus A, Szapary PO, Rader DJ, Zemel BS, Gilden-Tsai A (2012) A randomized trial of the effects of an almond-enriched, hypocaloric diet in the treatment of obesity. The Am j clin nutr 96(2):249-254

108. Praagman J, Beulens JW, Alssema M, Zock PL, Wanders AJ, Sluijs I, Van Der Schouw YT (2016) The association between dietary saturated fatty acids and ischemic heart disease depends on the type and source of fatty acid in the European Prospective Investigation into Cancer and Nutrition-Netherlands cohort, 2. The Am j clin nutr 103(2):356-365

109. Alonso A, Nettleton JA, Ix JH, de Boer IH, Folsom AR, Bidulescu A, Kestenbaum BR, Chambless LE, Jacobs DR Jr (2010) Dietary phosphorus, blood pressure, and incidence of hypertension in the atherosclerosis risk in communities study and the multi-ethnic study of atherosclerosis. Hypertension 55(3):776-784

110. Bolland MJ, Avenell A, Baron JA, Grey A, MacLennan GS, Gamble GD, Reid IR (2010) Effect of calcium supplements on risk of myocardial infarction and cardiovascular events: metaanalysis. Bmj 341:c3691

111. Faghih S, Abadi A, Hedayati M, Kimiagar S (2011) Comparison of the effects of cows' milk, fortified soy milk, and calcium supplement on weight and fat loss in premenopausal overweight and obese women. Nutr Metab Cardiovasc Dis 21(7):499-503

112. Ostlund RE Jr, Racette SB, Stenson WF (2002) Effects of trace components of dietary fat on cholesterol metabolism: phytosterols, oxysterols, and squalene. Nutri rev 60(11):349-359

113. Poneros-Schneier A, Erdman J Jr (1989) Bioavailability of calcium from sesame seeds, almond powder, whole wheat bread, spinach and nonfat dry milk in rats. J food sci 54(1):150-153

Publisher's note Springer Nature remains neutral with regard to jurisdictional claims in published maps and institutional affiliations. 